\title{
ASSESSING THE UK'S PUBLIC INTEREST TEST IN LIGHT OF SOCIETAL UNCERTAINTY
}

\author{
Annina Julia Kotamäki*
}

\begin{abstract}
This paper examines the long-standing debate on the regulation of foreign takeovers, and the protection of public interests by the government in relation to them, in light of societal uncertainty present in the UK. This uncertainty is being generated by two developments: Brexit and the rise of Artificial Intelligence. This paper argues that the task of regulating foreign takeovers should be viewed as one of balancing three objectives: the promotion of economic growth, the protection of public interest, and the management of social considerations resulting from these takeovers. Furthermore, it is argued that the current Public Interest Test should be restated for clarity and specificity. Finally, the creation of an independent body to administer the Public Interest Test and to negotiate social considerations that arise in relation to foreign takeovers is discussed, evaluated and endorsed.
\end{abstract}

\section{A. INTRODUCTION}

Professor Shamir wrote about the management of legal uncertainties during the New Deal era in the US, which occurred in the 1930s and 40s. He observed that during a crisis, 'old certainties have to be defended, and uncertainties knock on the door of established structures'. ${ }^{1}$ Much like the US following the Great Depression, the UK is facing an acute period of uncertainty and change. In the aftermath of Brexit, and as Artificial Intelligence (AI) and new technologies are beginning to be integrated into society, ${ }^{2}$ concerns about the precarious state of the economy have grown, ${ }^{3}$ and socially, people are feeling insecure and anxious about the future. ${ }^{4}$ The regulation of foreign takeovers and the protection of public interests in relation to them have been a long-standing topic of debate in the UK. ${ }^{5}$ Recently, Prime Minister Theresa May identified reforming the UK's Public Interest Test (PIT) as one of her government's priorities

\footnotetext{
* LLB (Hons) European Law School Programme (Maastricht University); LLM Corporate Law (University College London). The author would like to thank Anne, Kari, Sara and Elina for their endless support and encouragement, as well as the editors of this journal for their helpful comments and feedback on earlier versions of this paper.

${ }^{1}$ Ronen Shamir, Managing Legal Uncertainty: Elite Lawyers in the New Deal (Duke University Press 1995) 2.

2 Martin Arnold, 'Banks' AI plans threaten thousands of jobs' Financial Times (London, 25 January 2017) $<$ https://www.ft.com/content/3da058a0-e268-11e6-8405-9e5580d6e5fb > accessed 4 September 2017; Jane Croft, 'Artificial intelligence closes in on the work of junior lawyers' Financial Times (London 4 May 2017) $<$ https://www.ft.com/content/f809870c-26a1-11e7-8691-d5f7e0cd0a16> accessed 4 September 2017.

3 Mathew Lawrence, Future Proof: Britain in the 2020s (Institute for Public Policy Research 2016) 14 $<$ https://www.ippr.org/research/publications/future-proof-britain-in-the-2020s $>$ accessed 4 September 2017.

4 Thomas Oliver, 'A New British identity is key to Brexit's success. So who do we want to be?' The Guardian (London, 16 August 2017) <https:/www.theguardian.com/commentisfree/2017/aug/16/british-identity-keybrexit-crisis-negotiations $>$ accessed 4 September 2017.

${ }^{5}$ Antony Seely, Mergers \& takeovers: the public interest test (Commons Briefing Paper SN05374 2016).
} 
in the current environment of uncertainty. ${ }^{6}$ She emphasised that the UK's focus on attracting foreign investment should remain, but that social considerations should be given more weight. ${ }^{7}$ The Leader of the Opposition Jeremy Corbyn took this a step further recently, and stated that a future Labour government would enforce a broadening of the PIT. ${ }^{8}$ This paper discusses whether the UK's PIT should indeed be reformed, and examines the option of introducing a forum for social concerns arising in the context of foreign takeovers to be heard and assessed.

Social considerations, for the purposes of this paper, are defined as the anxieties and demands of society which can be inferred from political and popular perceptions and sentiment towards societal developments. Concerns that emerge in relation to foreign takeovers and which are mentioned in this paper revolve around the extraction of economic value (which covers job displacement), the protection of key national industries or companies, and tax avoidance by foreign companies. Social considerations should be distinguished from the concept of public interest. This author considers public interest to be a broad concept, comprised of a country's fundamental interests, general well-being and functioning at a given time.

This paper argues that the regulation of foreign takeovers should not provide a wide scope for government intervention, and in particular should resist protectionism, because foreign takeovers serve valuable functions. ${ }^{9}$ These functions are discussed in section B, which subsequently also provides an overview of the regulation of foreign takeovers in the UK, and explains the PIT. Thereafter, section C explains the complexity of the task of regulating foreign takeovers. It outlines the UK's regulation of foreign takeovers to date, and identifies the challenges to the task of regulating foreign takeovers presented by the effects of Brexit and the integration of AI into society. Section D establishes that there is a need for foreign takeover regulations in the UK to acknowledge social considerations, and reconceptualises the task of regulating foreign takeovers. Section E evaluates the current merger control regime in the UK,

\footnotetext{
${ }^{6}$ The Conservative and Unionist Party, Forward, Together: Our Plan for a Stronger Britain and a Prosperous Future (Manifesto 2017) 17 <https://www.conservatives.com/manifesto> accessed 4 September 2017.

${ }^{7}$ Prime Minister's Office, 'The Queen's Speech and Associated Background Briefing, on the occasion of the Opening of Parliament on Wednesday 21 June 2017' (21 June 2017) 17 $<$ https://www.gov.uk/government/uploads/system/uploads/attachment_data/file/620838/Queens_speech_2017_b ackground_notes.pdf $>$ accessed 4 September 2017.

${ }^{8}$ Rupert Neate, 'We will prevent hostile takeover bids for UK firms - Jeremy Corbyn' The Guardian (London, 20 February 2018) <https:/www.theguardian.com/politics/2018/feb/20/we-will-prevent-hostile-takeover-bidsfor-uk-firms-jeremy-corbyn> accessed 27 February 2018.

${ }^{9}$ Department for Business, Innovation and Skills 'Lord Mandelson, Secretary of State: Mansion House Speech' (Press $\quad$ notice 113010 ) $<$ http://webarchive.nationalarchives.gov.uk/20100304112545/http://www.bis.gov.uk/mansion-house-speech> accessed 4 September 2017.
} 
and then, section F outlines and evaluates suggestions for reform. Finally, Section G concludes this paper.

\section{B. BACKGROUND}

\section{The Desirability of Foreign Takeovers}

Protectionism, in the context of the discussion in this paper, refers to the shielding of capital and the control of national companies against foreign takeovers. A broadening of the PIT would constitute this kind of protectionism, as it would entail a widened scope for government intervention in foreign takeovers. This papers argues that such a broadening should not occur, because foreign takeovers are desirable. This desirability is explained below.

First, takeovers in general serve a valuable function in encouraging prudent management. More specifically, they are generally understood as being effective in reducing the agency costs which can arise from the imperfectly aligned relationship between shareholders and executives of companies. ${ }^{10}$ This reduction is achieved through a mechanism called the market for corporate control, which provides that Bidders are attracted to companies that have high agency costs because they present profitable opportunities. ${ }^{11}$ Upon acquiring such a company, the Bidder can remove incumbent management, and may profit from a resultant increase in the company's value. ${ }^{12}$ This potential for executives to be displaced encourages them to maintain minimal agency costs and maximise profitability and company performance. ${ }^{13}$ This mechanism is an accepted feature of Anglo-American corporate governance, ${ }^{14}$ and is facilitated where merger control is flexible and open, and takeovers can readily occur.

\footnotetext{
10 Jensen and Meckling are the key authorities on agency costs in Anglo-American corporate governance literature. They describe agency costs as a sum of: monitoring expenditures by the principal (shareholder), bonding expenditures by the agent (executive), and residual loss. See Michael Jensen and William Meckling, 'Theory of the Firm: Managerial Behaviour, Agency Costs and Ownership Structure' (1976) 3(4) Journal of Financial Economics 305, 310-311.

${ }^{11}$ For further details and a discussion of the limitations of the model of the market for corporate control, see: Marc Moore and Martin Petrin, Corporate Governance: Law, Regulation and Theory (Palgrave 2017) 57; Blanaid Clarke, 'Articles 9 and 11 of The Takeover Directive (2004/25) and the Market for Corporate Control' [2006] Journal of Business Law 355, 359-60; John Coffee, 'Regulating the Market for Corporate Control: a Critical Assessment of the Tender Offer's Role in Corporate Governance' (1984) 84 Columbia Law Review 1145, 1202 03; Julian Franks and Colin Mayer, 'Hostile Takeovers in the UK and the Correction of Managerial Failure' (1996) 40 Journal of Financial Economics 163, 180.

${ }^{12}$ David Kershaw, 'The Illusion of Importance: Reconsidering the UK's Takeover Defence Prohibition' (2007) 56 International \& Comparative Law Quarterly 267, 301; Moore and Petrin (n 11) 269.

13 ibid.

${ }^{14}$ Moore and Petrin (n 11).
} 
Secondly, foreign takeovers are generally considered key to stimulating economic activity. ${ }^{15}$ Encouraged by the country's favourable tax rates and relaxed merger control regime, the UK saw the economy gain more jobs out of Foreign Direct Investment (FDI) than any other country in Europe in 2015. ${ }^{16}$ Foreign takeovers can additionally produce synergies and economies of scale, thereby contributing to growth in economic productivity. ${ }^{17}$ Furthermore, they can provide cash injections for Target companies in need of them, allowing for projects facing abandonment to be completed, as well as for the servicing of debt which would otherwise have been defaulted upon. Finally, Target shareholders benefit from a premium when accepting a takeover offer, and can subsequently invest their wealth into new projects or spend it in the economy. ${ }^{18}$

These two reasons are commonly cited to justify why foreign takeovers are desirable by the Conservative government and the business and finance community, and also form the background of the remainder of this paper. However, it should be noted that various criticisms of these transactions have also been raised. Aeron Davis and colleagues provide a good summary of these. First, they point out the fact that takeovers are 'increasingly driven by shortterm profits and arbitrage rather than long-term investment and the development of companies'. ${ }^{19}$ Secondly, they observe that foreign takeovers have been linked to the decline of the UK's manufacturing industry. Thirdly, they argue that takeovers funded by significant proportions of debt may have a negative long term economic impact on the company which results after the transaction. ${ }^{20}$ Notwithstanding these criticisms, this article proceeds on the basis that foreign takeovers are, on balance, economically desirable.

\section{The Regulation of Foreign Takeovers in the UK}

a) Overview

The UK's PIT allows the Secretary of State to intervene in specific takeovers, where they are considered contrary to public interest. The PIT operates in the context of three merger control

15 Aeron Davis and others, 'Takeovers and the Public Interest: Responsible Capitalism in Practice' (Policy Network 2013) 4 <http://www.policy-network.net/publications_detail.aspx?ID=4435> accessed 4 September 2017.

16 Steve Varley and Mark Gregory, 'EY's Attractiveness Survey: UK 2016: Positive rebalancing?' (Ernst and Young 2016) <www.ey.com/Publication/vwLUAssets/2016-UK-Attractiveness-Survey/\$FILE/EY-UKAttractiveness-Survey-2016.pdf $>$ accessed 4 September 2017; Alex Potter, 'The Foreign Investment Regulation Review United Kingdom' in Brian Facey (ed), TLR: The Foreign Investment Regulation Review (4th edn, Law Business Research Ltd 2016).

17 New Direction Foundation, 'The Economic Advantages and Disadvantages of Foreign Takeovers' (August 2014) 9 <http://europeanreform.org/files/New_Direction_-_Foreign_Takeovers.pdf $>$ accessed 4 September 2017. 18 ibid.

${ }^{19}$ Davis and others (n 15) 7.

20 ibid 5-6. 
regulations, which are all applicable to foreign takeovers. A brief overview of these is provided below.

First, if the concentration which would arise from an attempted takeover satisfies the EU Merger Regulation's (EUMR) turnover thresholds and therefore has an 'EU dimension', an EU competition review is triggered. ${ }^{21}$ This entails that the EU Commission has exclusive jurisdiction to assess the competition effects of that takeover. ${ }^{22}$

Secondly, where a proposed takeover does not have an 'EU dimension', national competition law is applicable. The Enterprise Act 2002 (EA 2002) designates the Competition and Markets Authority (CMA) as the regulatory body for the competition aspects of merger control, ${ }^{23}$ and also contains the PIT. ${ }^{24}$ However, only 'relevant merger situations' are reviewable by the CMA and fall within the scope of the PIT. These arise where a change of control or common ownership over two or more enterprises occurs, and either the UK turnover of the Target company is greater than $£ 70$ million, or the merger creates a $25 \%$ share of supply or purchases of the goods or services of a particular description in the UK, or in a substantial part of it. ${ }^{25}$

Finally, when a takeover of a UK public company is attempted, the UK's Takeover Code (the Code) sets the timeline and provides a framework for the deal-making process that ensues. ${ }^{26}$ The overarching purpose of the Code is to 'promote, in conjunction with other regulatory regimes, the integrity of financial markets'. ${ }^{27}$

\section{b) Explaining the Structure of the Public Interest Test}

The key objectives of the 2001 Labour Government in enacting the EA 2002 were to remove politics from decisions on public takeovers, ${ }^{28}$ to make these decisions competition-focused, ${ }^{29}$ and to increase business certainty in the UK. ${ }^{30}$ A purely competition-based test was introduced to regulate proposed mergers, and an independent competition authority, the CMA, was

${ }^{21}$ Council Regulation (EC) 139/2004 of 20 January 2004 on the control of concentrations between undertakings [2004] OJ L24/1 (EUMR) arts 1-3.

22 ibid arts 2-3.

${ }^{23}$ Enterprise and Regulatory Reform Act 2013, pt 3.

${ }^{24}$ Enterprise Act 2002 (EA 2002), Part 3, Chapter 2.

${ }^{25}$ EA 2002, s 23.

${ }^{26}$ The Panel on Takeovers and Mergers, 'The Takeover Code' (12 September 2016) (The Takeover Code) $<$ http://www.thetakeoverpanel.org.uk/wp-content/uploads/2008/11/code.pdf?v=20Jul2017> $\quad$ accessed 4 September 2017.

27 The Takeover Code, Introduction 2(a).

28 The original PIT was contained in the Fair Trading Act 1973 and provided that ministers made decisions regarding mergers taking into account any matter which appeared to be relevant to a merger's desirability. See Fair Trading Act 1973, s 84.

${ }^{29}$ Department of Trade and Industry, A World Class Competition Regime (Cm 5233, 2001$) 15$.

${ }^{30}$ ibid; Duncan Liddell and Ruth Allen, 'The Public Interest Merger Regime' in Nigel Parr and others (eds), $U K$ Merger Control Law and Practice (3rd edn, Sweet and Maxwell 2016) 700. 
instituted. ${ }^{31}$ In addition to this, the current PIT was created, giving the Secretary of State competence to intervene in proposed takeovers in the three specific circumstances outlined below. 32

First, EA 2002 enables the Secretary of State to issue a public interest intervention notice where a proposed takeover is reviewable under UK competition law and a public interest consideration outlined in section 58 of EA 2002 arises. ${ }^{33}$ Secondly, the Secretary of State can issue a European intervention notice if a proposed takeover is reviewable under the EUMR, and a legitimate interest of the UK is perceived as being under threat, or a public interest consideration is applicable. ${ }^{34}$ Finally, the Secretary of State can issue a special interest intervention notice where a proposed takeover does not meet the thresholds for a competition review, but a public interest consideration has nevertheless arisen. For the issuance of a special interest intervention notice, the proposed takeover must also concern an enterprise managed by a government contractor, or be one which substantially affects the country's supply of newspapers or its provision of broadcasting. ${ }^{35}$

c) The Substance of the Public Interest Test: Public Interest Considerations

i) National Security

The first public interest consideration is that of 'national security'. Pursuant to section 58(2), this includes 'public security', which is to be understood as having the same meaning as in article 21(4) of the EUMR. ${ }^{36}$ However, article 21(4) of the EUMR 'does not expressly define "public security". ${ }^{37}$ Instead, in defining public security for the purposes of article 21(4), the European Commission refers to a variety of case law related to the application of article 36 of the TFEU. ${ }^{38}$ Liddell and Allen summarise the definition of public security as follows:

it would appear that the notion of 'public security' [...] applies to internal and external military security, but may also extend to other non-economic matters which threaten the well-being of the UK, such as the protection of the population's health or security of supply of a product that is of fundamental importance for the country. ${ }^{39}$

\footnotetext{
${ }^{31}$ Department of Trade and Industry (n 29) 3.

${ }^{32}$ EA 2002, s 42, 59, 67.

${ }^{33}$ ibid s $42,58$.

${ }^{34}$ EUMR, arts 1-3, 21(4); EA 2002, s 67.

${ }^{35}$ EA 2002, s 59.

${ }^{36}$ EA 2002, s 58(2); EUMR, art 21(4).

${ }^{37}$ EUMR, art 21(4); Liddell and Allen (n 30) 702.

${ }^{38}$ Liddell and Allen (n 30) 702; Consolidated Version of The Treaty on the Functioning of the European Union [2012] OJ C326/47 (TFEU), art 36.

${ }^{39}$ Liddell and Allen (n 30) 704.
} 
Campus Oil v Minister for Industry and Energy is particularly relevant to establishing the UK's position on the definition of public security. ${ }^{40}$ In this case, Ireland sought to justify a law that constituted a quantitative restriction on imports of refined petroleum products, contrary to what is now article 34 of the TFEU, on the grounds of public policy and public security. ${ }^{41}$ Ireland argued that the law was geared towards supporting the country's last remaining oil refinery, with the objective of avoiding a situation of dependence on foreign imports. ${ }^{42}$ Notably, the UK's submissions in respect of this case emphasised the need for public security to be interpreted narrowly. It was specifically reiterated in the UK's submissions that public security measures should not be directed towards attaining primarily economic objectives, and argued that public security should only cover 'the fundamental interests of the state such as the maintenance of essential public services or the safe and effective functioning of the life of the state'. ${ }^{43}$

The UK's strict position on public security is reflected in the narrow application of the national security consideration in practice. To date, interventions by the Secretary of State on the basis of national security considerations have only occurred in relation to proposed takeovers considered likely to impact defence operations. These cases generated concerns regarding the maintenance of the UK's strategic capabilities and the protection of classified information or technologies. ${ }^{44}$ Furthermore, when these interventions were taken by the Secretary of State, conditions, known as Undertakings in Lieu of Reference (UILs), were subsequently negotiated and secured between the Secretary of State and the parties to the proposed takeover, pursuant to section 73 of the EA 2002. ${ }^{45}$ This allowed the relevant national security considerations to be mitigated, and for takeovers to be completed despite having received interventions. ${ }^{46}$

ii) Media Plurality and Accurate Presentation of the News

The second consideration protects the need for media plurality and accurate presentation of the news. ${ }^{47}$ This paper's focus is limited to the more general public interest

\footnotetext{
${ }^{40}$ Case 72/83 Campus Oil v Ministry for Industry and Energy [1984] ECR 2727.

41 TFEU, art 34.

${ }^{42}$ Campus Oil (n 40).

43 ibid para 23.

${ }_{44}$ Jonathan Parker and Adrian Majumdar, UK Merger Control (2nd edn, Hart Publishing 2016) 152-156; Alex Chisholm and Nelsen Jung, 'The Public Interest and Competition-Based Scrutiny of Mergers: Lessons from the Evolution of Merger Control in the United Kingdom' (2014) 10(1) CPI Antitrust Chronicle $<$ https://www.competitionpolicyinternational.com/assets/Uploads/ChisholmJungOCT-141.pdf $>$ accessed 4 September 2017.

${ }^{45}$ EA 2002, s 73.

${ }^{46}$ Parker and Majumdar (n 44) 152.

${ }^{47}$ EA 2002, ss 58(2A)-(2C).
} 
considerations in section 58(2) and (3) because media mergers are governed by more specific rules than mergers in general, and additionally involve the UK's Office of Communications in the context of the application of the PIT. ${ }^{48}$

iii) The 'Open' Public Interest Consideration

The final consideration is effectively an open one. It allows the Secretary of State to specify, with parliamentary approval, a new public interest consideration in relation to a proposed merger. ${ }^{49}$ To date, this consideration has only been used in relation to the takeover of HBOS Plc (HBOS) by Lloyds TSB (Lloyds) which occurred during the 2008 financial crisis. ${ }^{50}$ In this case, the Secretary of State issued an intervention notice to protect the stability of the UK's financial system. This was considered necessary as HBOS was deemed to be an integral part of the UK's financial system. The merger was, however, ultimately approved because it was concluded that its completion would have a greater positive than negative effect on the financial system. ${ }^{51}$

Whilst the HBOS/Lloyds takeover has thus far been the only occasion upon which the Secretary of State has used section 58(3), there is a growing level of pressure for the Secretary of State to extend the scope of possible interventions in order to shield key areas of the UK economy and British companies that own 'critical infrastructure and/or receive public funding to conduct research and development' from public takeovers. ${ }^{52}$ This 'open' consideration provides the tool for the scope to be increased.

\section{d) The Role of the Takeover Panel}

The General Principles and Rules of the Code are intended to ensure that a Bidder company's activities do not disregard Target shareholder interests, unduly disrupt markets, or interrupt the operations of a Target company unnecessarily. ${ }^{53}$

The Code provides in its introduction that the financial and commercial aspects of a takeover are irrelevant to its purpose, and that it does not seek to 'facilitate or impede takeovers', nor is it 'concerned with those issues, such as competition policy, which are the responsibility of government and other bodies'. ${ }^{54}$ There is therefore a clear distinction between the procedural regulation achieved by the Code on the one hand, and the competition law and

\footnotetext{
${ }^{48}$ On this, see: Mike Feintuck, 'The Public Interest' in Regulation (OUP 2004) 114-115; Mark Furse, The Law of Merger Control in the EC and the UK (Hart Publishing 2007) 284-286.

${ }^{49}$ EA 2002, s 58(3).

${ }^{50}$ Liddell and Allen (n 30) 725.

51 ibid.

52 ibid 727.

53 The Takeover Code, General Principles 1-6.

54 ibid, Introduction 2(a).
} 
more policy-related roles of the CMA and the Secretary of State on the other. This distinction is emphasised by the Panel's independent, self-regulatory nature, and by the fact that the Code was created as an instrument of self-regulation by professionals from industries active in takeovers. $^{55}$

Regarding controversial foreign takeovers, the Code most notably provides a framework which distinguishes between post-offer undertakings and post-offer intention statements. ${ }^{56}$ The former are statements by a party to a transaction which indicate the party's commitment to take a course of action or to refrain from doing so after its offer period is complete. The latter are statements which outline that a party to a transaction merely intends to take a particular course of action, or to refrain from doing so after its offer period is complete. ${ }^{57}$ Post-offer intention statements are required to be made accurately and on reasonable grounds, and the party that makes them is further expected to update the Panel on any progress related to the party's intention as provided in its statement. ${ }^{58}$ The rule concerning post-offer undertakings is more burdensome. It provides that these undertakings must be specific, precise, readily understandable, capable of objective assessment, and must not be dependent on subjective judgments of the party to the offer or its directors. ${ }^{59}$ Furthermore, they must state a deadline for completion, and clearly outline qualifications or conditions. ${ }^{60}$ The Code also provides that having made a post-offer undertaking, a party must report to the Panel at intervals and in the form required by the Panel, and that the Panel may appoint a supervisor to monitor compliance with a given undertaking. Section 955 of the Companies Act 2006 allows the Takeover Panel to request court enforcement of the rules provided in the Code. ${ }^{61}$ Companies are however unlikely to willingly enter into commitments via post-offer undertaking statements, due to this more rigorous level of oversight.

\section{THE CHALLENGE OF THE PUBLIC INTEREST TEST}

\section{The Complexity of Regulating Foreign Takeovers}

\footnotetext{
${ }^{55}$ Andrew Johnston, 'Takeover Regulation: Historical and Theoretical Perspectives on the City Code' (2007) 66 CLJ 422, 432; Moore and Petrin, (n 11) 57.

56 The Takeover Code, rr 19.5-19.6.

57 The Takeover Panel, 'Post-Offer Undertakings and Intention Statements: Response Statement by the Code Committee of the Panel Following the Consultation on PCP 2014/2' (23 December 2014) para 1.3 $<$ http://www.thetakeoverpanel.org.uk/wp-content/uploads/2008/11/RS201402.pdf > accessed 4 September 2017.

58 The Takeover Code, r 19.6.

${ }^{59}$ ibid r 19.5(c).

60 ibid r 19.5(b).

${ }^{61}$ Companies Act 2006, s 955; The Takeover Code, Introduction 10(d).
} 


\section{a) A Choice Between Pursuing Economic Objectives and Protecting Social}

\section{Considerations}

Broadly speaking, in fulfilling the task of regulating foreign takeovers, governments face a choice between encouraging them, restricting them, or somehow finding a consensus between these two options. This simplified conception provides a foundation for the discussion and arguments set out in this paper.

The two options of either encouraging foreign takeovers or restricting them symbolise a conflict of ideas taking shape across global politics: one between globalisation and neoliberalism on the one hand, and economic nationalism on the other. ${ }^{62}$ Countries which have chosen to encourage takeovers and align more with the former movements, like the UK, have done so for economic motives. ${ }^{63}$ Countries which tend to choose to be more restrictive in relation to foreign takeovers, like France, have done so out of greater appreciation of the need to protect other national interests, including social considerations. ${ }^{64}$ These choices between promoting economic growth and protecting national interests illustrate how politically sensitive and complex the task of regulating foreign takeovers is.

\section{b) The Controversy of Foreign Takeovers}

Regulating foreign takeovers is furthermore a complex task because such transactions are controversial by nature. Joongi Kim's work helps to contextualise this. He explains that protectionist impulses in relation to foreign ownership stem from the increasing globalisation of business as well as from mercantilist impulses. ${ }^{65}$ Kim describes mercantilist impulses as desires to attempt to "promote the investment activity of domestic firms in international markets [whilst also seeking to employ] protectionist policies [in order] to preserve domestic firm competitiveness' ${ }^{66}$ He notes that foreign takeovers are particularly contentious when they are unsolicited or hostile, attempted within key industries or during times of economic uncertainty ${ }^{67}$ Foreign ownership in these instances in particular is perceived as unfamiliar and unpredictable, and this perception, according to Kim, is encouraged by fear of the unknown, concerns about dependency on foreign interests, xenophobia as well as by 'double standards

\footnotetext{
${ }^{62}$ Joongi Kim, 'Fears of Foreign Ownership: The Old Face of Economic Nationalism' (2007) 27 SAIS Review of International Affairs 167, 172.

${ }^{63}$ Liddell and Allen (n 30), 728-729.

${ }^{64}$ ibid; Kim (n 62) 169.

${ }^{65} \mathrm{Kim}(\mathrm{n} 62), 173$.

${ }^{66}$ ibid 167.

${ }^{67}$ ibid 173.
} 
for foreign markets versus local markets' ${ }^{68}$ These factors thus explain why concerns related to foreign takeovers identified in the introduction to this paper arise.

Foreign takeovers have become increasingly controversial in the UK over the last decade, ${ }^{69}$ and have generated significant debate about reforming the PIT. ${ }^{70}$ Despite this, and as outlined in the following section, the UK has generally maintained a position of championing free trade, open markets and flexible regulation.

\section{The UK's Regulation of Foreign Takeovers to Date}

The UK's commitment to resisting increasing demands for protectionism via a broadening of the PIT was first tested in 2006, when concerns were voiced about the security of energy supplies in the UK market in light of Russian PAO Gazprom's bid for Centrica Plc, the parent company of British Gas Plc. The Department for Trade and Industry reportedly considered reforming merger control in order to revert back from the competition-based PIT to allowing ministers the opportunity to block an attempted takeover where both economic and national interests were at stake. ${ }^{71}$ However, no reforms ultimately materialised, as Prime Minister Tony Blair clarified that the UK would persist with its commitment to liberalised markets. ${ }^{72}$

The takeover of Cadbury Plc (Cadbury) by Kraft Foods Inc. (Kraft) in 2010 presented the next challenge to the UK's liberal position. This takeover succeeded but was highly controversial as Kraft publicly announced that, post-acquisition, it believed that it would be able to continue operating Cadbury's factory facility in Somerdale, thereby preserving British jobs. However, Cadbury was in fact already in the process of closing this facility, and so, a

\footnotetext{
68 ibid 174-175.

${ }^{69}$ For example, the statistics on the public perception of foreign takeovers show that in $2014,53 \%$ of people in the UK perceived foreign takeovers in a negative light. The remaining figures show that $5 \%$ of people believed foreign companies buying domestic companies was very good, 34\% said it was somewhat good, and 7\% skipped this question, or did not know what they thought. See: Bruce Stokes and Russ Oates, 'Faith and Skepticism about Trade, Foreign Investment' (2014) Pew Research Center Global Attitudes Survey, 39 $<$ http://assets.pewresearch.org/wp-content/uploads/sites/2/2014/09/Pew-Research-Center-Trade-Report-FINALSeptember-16-2014.pdf> accessed 4 September 2017.

${ }^{70}$ Leo McCann, International and comparative Business: Foundations of Political Economies (Sage Publications 2014) 83-85, 110; Martin Jacques, 'The death of neoliberalism and the crisis in western politics' The Guardian (London, 21 August 2016) <https://www.theguardian.com/commentisfree/2016/aug/21/death-of-neoliberalismcrisis-in-western-politics $>$ accessed 4 September 2017.

${ }^{71}$ Note, as discussed in (n 28), prior to the enactment of EA 2002 the original PIT contained in the Fair Trading Act 1973, s 84, provided that ministers made decisions regarding mergers taking into account any matter which appeared to be relevant to a merger's desirability; Mark Milner, 'Gazprom threatens Europe's gas supply' The Guardian (London, 21 April 2006) <https://www.theguardian.com/business/2006/apr/21/russia > accessed 4 September 2017; James Blitz and Stefan Wagstyl, 'Blair rules out blocking Gazprom Centrica bid' Financial Times (London, 25 April 2006) <https://www.ft.com/content/a5013014-d496-11da-a357-0000779e2340> accessed 4 September 2017.

72 It should be noted that this response may also have been influenced by concerns about the scarcity of future gas supplies outside of Russia. See ibid.
} 
week after the takeover was declared unconditional, Kraft announced that it was no longer able to reverse Cadbury's plans to close it. ${ }^{73}$

Kraft's failure to adhere to its statement was met with public disapproval and was unfavourably received by the Takeover Panel, which issued a statement of criticism against Kraft. ${ }^{74}$ A consultation was conducted by the Code Committee, and amendments to the Takeover Code were made. These included extended disclosure requirements applicable to Bidder companies that made statements about their intentions concerning Target companies and their businesses. ${ }^{75}$ However, these amendments are not considered to have had a major impact in practice, and did not broaden the PIT. ${ }^{76}$

No reforms to the PIT resulted from Pfizer Inc.'s (Pfizer) failed attempted takeover of UK-based Astra Zeneca Plc (AstraZeneca) in 2014 either, despite heated debate and significant concerns about the implications of the takeover and Pfizer's motivations. These related to the foreign ownership of a company in a strategic British industry, ${ }^{77}$ and Pfizer's motivations in acquiring AstraZeneca, which were perceived as problematic because it appeared that the acquisition was not for long-term strategic purposes, but rather to reduce Pfizer's tax bill. ${ }^{78}$ Prime Minister David Cameron fended off demands for reform of the PIT whilst the takeover was still progressing by requiring the Cabinet Secretary to obtain assurances from Pfizer concerning commitments relating to jobs, factory locations, investment and science. ${ }^{79}$

Following the controversy that arose during the attempted takeover of AstraZeneca by Pfizer, the Takeover Code was amended to include rules 19.5 and 19.6 - the current framework

\footnotetext{
${ }^{73}$ Blanaid Clarke, 'Directors' Duties in a Changing World: Lessons from the Cadbury Plc Takeover' (2010) 7 European Company Law 204, 205-10.

74 'Kraft Foods Inc. ("Kraft") offer for Cadbury Plc ("Cadbury")' (The Takeover Panel, 26 May 2010) $<$ http://www.thetakeoverpanel.org.uk/wp-content/uploads/2009/12/2010-14.pdf $>$ accessed 4 September 2017.

${ }^{75}$ Michael Hatchard and Scott Hopkins, 'U.K. Takeover Code - Changes Effective September 19, 2011' (Skadden Memorandum $21 \quad$ September $\quad 2011)$ $<$ https://files.skadden.com/newsletters\%2FUK_Takeover_Code_Changes_Effective_September_19_2011.pdf $>$ accessed 4 September 2017.

76 ibid; William Charnley and Connor Cahalane, 'Changes to the Takeover Code and how they are likely to affect UK deals' (Mayer Brown, December 2011) < https://www.mayerbrown.com/Files/News/369c0470-be5f-4d3f9fadf2400b89b823/Presentation/NewsAttachment/67cad390-bf58-4899-bdd4-

f3b6d0c7069c/art_charnley_cahalane_dec11_takeover-code.pdf $>$ accessed 4 September 2017.

77 Patrick Wintour, 'I'm not satisfied with Pfizer's bid for AstraZeneca, says David Cameron' The Guardian (London, 7 May 2014) <https://www.theguardian.com/business/2014/may/07/not-satisfied-pfizer-bidatrazeneca-david-cameron> accessed 4 September 2017; Rob Davies and Dominic Rushe, 'Pfizer takeover: what is a tax inversion deal and why are they so controversial?' The Guardian (London, 23 November 2015) $<$ https://www.theguardian.com/business/2015/nov/23/pfizer-takeover-tax-inversion-questions $>$ accessed 4 September 2017.

${ }^{78}$ Katie Thomas and Chad Bray, 'Pfizer Faces Limited Options After its Dead Deal with Allergan' New York Times (New York City, 6 April 2016) <https://www.nytimes.com/2016/04/07/business/dealbook/pfizer-allerganmerger.html?mcubz=1> accessed 4 September 2017.

${ }^{79}$ Wintour (n 77).
} 
for post-offer undertakings and post-offer statements, previously discussed in section B. These rules were considered necessary for the purpose of providing clarity for shareholders and other stakeholders with respect to statements made by Bidders regarding their intentions following an offer, for improving the Panel's ability to enforce commitments entered into by Bidders, and for enabling Bidders and Target companies to make informative statements of intention. ${ }^{80}$ It has been suggested that this framework was introduced by the Takeover Panel pre-emptively, to avoid the introduction of increased intervention via reform of the PIT due to growing concerns about foreign ownership in industries considered to be of exceptional national importance. ${ }^{81}$

In summary, although tensions that arose as a result of these takeovers generated substantial political debate, the UK's merger control regime has for the most part not succumbed to protectionist pressures to broaden the PIT.

\section{Disruptive Societal Developments and their Implications for the UK's Merger Control Regime}

Two developments currently taking shape are having a disruptive effect on society in the UK. This section discusses the anticipated impact of these developments on public and political perceptions of foreign takeovers, and consequently the impact these developments have on the way the task of regulating such takeovers should be perceived in the UK.

a) Brexit

The UK voted in a referendum to exit the EU in June 2016, and is currently conducting negotiations with the EU concerning its future position as a non-member state. ${ }^{82}$ The UK must now change how it projects itself on the global stage, and must disentangle itself from the EU. These tasks will be a considerable source of political, social and economic uncertainty for the foreseeable future.

Social and political unrest over multiculturalism, national identity and the effect of globalisation were contentious issues leading up to the referendum, and are anticipated to remain as such whilst the government tackles the implications of Brexit. ${ }^{83}$ The UK's economy is expected to suffer in terms of investment and employment as the government begins to make

\footnotetext{
80 The Takeover Panel (n 57).

${ }^{81}$ Alex Kay and Caroline Rae, 'Protectionism in UK M\&A - the Legal Landscape and Changing Attitudes' in Scott Hopkins and Lorenzo Corte (eds), Mergers and Acquisitions 2017 (11th edn, Global Legal Group 2017).

82 Prime Minister's Office, 'EU referendum (Archived)' (17 August 2016)

$<$ http://webarchive.nationalarchives.gov.uk/20160817104546/https://www.gov.uk/government/topicalevents/eu-referendum $>$ accessed 4 September 2017.

83 ibid; Lui Hebron and John Stack, Globalization, and Debunking the Myths (Rowman \& Littlefield 2017$) 17$.
} 
the necessary changes for the nation's transition to a non-member state, ${ }^{84}$ and similarly, given the level of social integration that being a member state of the EU brought about, the concept of British identity will require fresh consideration for many, particularly in London. ${ }^{85}$

This paper submits that whilst the future of the nation post-Brexit remains unclear, all three types of uncertainty resulting from Brexit (economic, social and political), will have the effect of solidifying negative public and political perceptions of foreign takeovers, causing them to become increasingly emotionally charged. ${ }^{86}$ As a result, the importance of recognising social considerations in relation to foreign takeovers has grown, relative to that of resisting protectionism in order to pursue economic growth.

\section{b) The Integration of Artificial Intelligence into Society}

AI presents many positive opportunities for economic growth, productivity and the expansion of human capabilities in various sectors. It is also something the government is seeking to encourage and support in the UK. ${ }^{87}$ However, these expected benefits bring with them various societal and ethical concerns, particularly in relation to job displacement. ${ }^{88}$ Job displacement is a key concern because AI makes it possible for 'firms and people [to] use resources more efficiently, and [to] streamline the way we interact with large sets of data', as well as for 'routine administrative and operational jobs [to] be learned by software agents'. ${ }^{89}$ The Bank of England estimates that 'two-thirds of current jobs are at risk of automation, with the lower paid

\footnotetext{
${ }^{84}$ László Andor, 'The Economic and Social Consequences of Brexit' (Festival of Ideas, York, 16 June 2016) 5 $<$ https://www.boeckler.de/pdf/v_2016_06_16_vortrag_andor.pdf $>$ accessed 4 September 2017; Lawrence (n 3); Nils Pratley, 'Bosses are right: political uncertainty will damage the economy' The Guardian (London, 12 June 2017) <https://www.theguardian.com/business/nils-pratley-on-finance/2017/jun/12/uk-political-uncertaintybrexit-eu> accessed 4 September 2017.

${ }^{85}$ Richard Ashcroft and Mark Bevir, 'Pluralism, National Identity and Citizenship: Britain after Brexit' (2016) 87 The Political Quarterly 355.

86 A study by Thomas Landsall-Welfare and colleagues substantiates this prediction. It examined society's response to social tension and economic downturn, concluding that these events are quickly reflected in public opinion and sentiment in the UK, and that public anger and fear run high in the period that precedes particularly concerning expressions of public dissatisfaction. See Thomas Landsall-Welfare and others, 'Effects of the Recession on Public Mood in the UK' (WWW 2012 Companion 2012) $<$ https://www.researchgate.net/profile/Vasileios_Lampos/publication/228439030_Effects_of_the_Recession_on _Public_Mood_in_the_UK/links/53ec0db90cf202d087d00c06.pdf $>$ accessed 4 September 2017; see also Kim (n 62) 173, on how the controversy of foreign takeovers increases in 'economically pressing times'.

87 Professor Dame Wendy Hall and Jérôme Pesenti, 'Growing the Artificial Intelligence Industry in the UK' < https://www.gov.uk/government/uploads/system/uploads/attachment_data/file/652097/Growing_the_artificial_i ntelligence_industry_in_the_UK.pdf $>$ accessed 20 January 2018 8-14.

88 'Introduction from the founding co-chairs' (Partnership on AI to benefit people and society, 2017) $<$ https://www.partnershiponai.org/introduction/> accessed 4 September 2017; Arnold (n 2); Croft (n 2).

${ }^{89}$ Government Office for Science, '2016 Report, Artificial Intelligence: Opportunities and implications for the future of decision-making' <https:/www.gov.uk/government/publications/artificial-intelligence-an-overviewfor-policy-makers> accessed 20 January 2018.
} 
generally most at risk'. ${ }^{90}$ Job displacement is therefore going to become an increasingly prevalent concern as technology continues to develop and as AI is integrated into society.

The technology industry is conscious of the fact that societal disruption will ensue as $\mathrm{AI}$ is rolled out. Recognition of growing societal anxiety was for example seen early last year at the World Economic Forum in Davos. ${ }^{91}$ Attendees of the Forum reportedly focused less on the potential for growth and efficiency presented by AI, and devoted more thought towards 'the consequences [of $\mathrm{AI}$ ] for the humans caught on the wrong side of technological progress' ${ }^{92}$

This awareness and discussion of pending disruption caused by AI at an industry level is a welcome development. However, jobs traditionally completed by humans being lost to software or becoming redundant due to the emergence of new technologies will nevertheless induce a difficult period of societal restructuring and adjustment. During this period, it is foreseeable that public and political perceptions towards foreign takeovers will be considerably aggravated, ${ }^{93}$ particularly as these takeovers are often perceived as threats to national jobs. ${ }^{94}$ Whilst the uncertainty generated by AI is not as immediate as that which has been caused by Brexit, it is nevertheless significant, and will emerge in the long term.

It is important for foreign takeover regulations in the UK to be able to withstand the uncertainty associated with both AI and Brexit, and in light of this, it is submitted that the UK's acknowledgement of social considerations that arise in relation to foreign takeovers should be improved. This argument is substantiated in the following section of this paper.

\section{RECONCEPTUALISING THE TASK OF REGULATING FOREIGN TAKEOVERS: THE NEED TO ACKNOWLEDGE SOCIAL CONSIDERATIONS}

\section{The Need to Acknowledge Social Considerations in the Regulation of Foreign}

\section{Takeovers}

As discussed in sections $\mathrm{B}$ and $\mathrm{C}$, the acknowledgement of social considerations is currently an optional component of the process of regulating foreign takeovers, pursuant to the possibility of using the open consideration under section 58 and the rules on post-offer undertakings and statements of intention. ${ }^{95}$ Social considerations are seen as external to the

\footnotetext{
${ }^{90}$ Lawrence (n 3).

${ }^{91}$ Tim Bradshaw, 'Tech leaders at Davos fret over effect of AI on jobs' Financial Times (Davos, 20 January 2017)

$<$ https://www.ft.com/content/744ad7fa-de66-11e6-9d7c-be108f1c1dce> accessed 4 September 2017.

92 ibid.

${ }^{93}$ Landsall-Welfare and others (fn 81).

${ }^{94}$ Wintour (n 77); Clarke (n 11) 204.

95 The Takeover Panel (n 57).
} 
process of the operation of the current merger control regime, as it lacks specific processes to determine how social considerations should be responded to in a formalised manner, and pressure in relation to them can only be exerted from outside the regime.

In light of the above discussion of disruptive societal developments occurring in the UK, this author argues that social considerations arising in relation to foreign takeovers should be more explicitly recognised in the legal framework governing such transactions. More specifically, this author argues that it is important that the law provides a forum for social considerations to be heard and assessed for two main reasons.

First, providing such a forum would allow for flexibility and responsiveness to prevailing social norms and values. Recognising negative public perceptions of foreign takeovers in the legal framework for the review of foreign takeovers would mitigate the controversy of these transactions in public discourse. Secondly, introducing a clear formal process for the acknowledgement of social considerations would also reduce the ability of politicians to intervene in foreign takeovers in an ad hoc informal manner, as well as the emergence of other external pressures which hinder the materialisation of a takeover attempt.

\section{a) A Constructive and Progressive Approach to Uncertainty Generated by Foreign}

\section{Takeovers}

Joseph Stiglitz's work supports the argument for regulating foreign takeovers in a way which reflects a greater inclusion of social considerations. He argues that when faced with uncertainty and societal challenges, people demand security, which generally invokes a reaction by the government of either reducing security threats through protectionism, or reinforcing systems of social protections. ${ }^{96}$

In adherence to the position that a protectionist reaction is undesirable (articulated at the outset of this paper), this author submits that acknowledging social considerations in the regime governing foreign takeovers and providing a forum for them to be heard and assessed would constitute a constructive and progressive response to the uncertainty that foreign takeovers generate. Such a forum would enhance the merger control regime's flexibility and responsiveness to public perceptions of foreign takeovers, promoting greater feelings of security and trust in the public in relation to such transactions. It would thus enable society to more efficiently weather the uncertainty and anxiety generated by foreign takeovers and would

\footnotetext{
${ }^{96}$ Joseph Stiglitz, 'Social Protection Without Protectionism' in Joseph Stiglitz and Mary Kaldor (eds), The Quest for Security: Protection without Protectionism and the Challenge of Global Governance (Columbia University Press 2013) 27, 43.
} 
mitigate the controversy these transactions generate. ${ }^{97}$ Additionally, such a forum could encourage companies involved in foreign takeovers to appreciate public interests and concerns and respond in good faith.

\section{b) Reinforcing the Process by which Foreign Takeovers are Reviewed}

This section first describes two takeovers which failed to materialise in 2015 and 2017. From the description of these takeovers it is concluded that the process by which foreign takeovers are reviewed should be reinforced, as the process is currently susceptible to circumvention by politicians, and its effectiveness is hampered by external pressures. A forum for the acknowledgement of social considerations arising out of foreign takeovers is discussed as a method by which the review process can be reinforced.

i) The Deterred Potential Attempt to Takeover BP by ExxonMobil

In late 2015, there was speculation that the American multinational, ExxonMobil Corp. (ExxonMobil) was considering a takeover of BP Plc (BP), as BP's share price had taken a significant hit following the Deepwater Horizon disaster in the Gulf of Mexico in 2010, making it a lucrative target. ${ }^{98}$ In response to this speculation, David Cameron firmly announced that any attempt to takeover BP would be opposed by the UK government, given constraints on the supply of oil and concerns about loss of a national industry champion. ${ }^{99}$ It is believed that the government's openly-expressed resistance ultimately deterred ExxonMobil from issuing an offer for BP. ${ }^{100}$

Given the government's commitment to liberalised markets and its favourable attitude towards foreign takeovers in the past, it is noteworthy that Cameron stepped in to guard BP from foreign investors before a takeover had even materialised. He did this despite evidence that BP had been struggling to maintain its performance for over a decade, ${ }^{101}$ and that an acquisition of BP might have been beneficial in helping to improve the company's performance. ${ }^{102}$

Analyst speculations are assumed to have generated concern in the UK about the supply of oil, which likely partially explains Cameron's decision to seek to protect BP. ${ }^{103}$ However,

\footnotetext{
97 ibid.

${ }^{98}$ Christopher Adams, 'BP's battles leave it vulnerable to major move' Financial Times (London, 15 February $2015)<$ https://www.ft.com/content/d23fe0ac-af7f-11e4-a418-00144feab7de> accessed 4 September 2017.

${ }^{99}$ George Parker and Christopher Adams, 'UK government warns BP over potential takeover' Financial Times (London, 26 April 2015) <https://www.ft.com/content/06a3207e-e901-11e4-87fe-00144feab7de> accessed 4 September 2017.

100 ibid.

101 Adams (n 98).

102 Particularly as US legal proceedings concerning BP's Deepwater Horizon liabilities were yet to reach a conclusion at the time, see ibid.

103 ibid.
} 
further explanation for his decision can be found in the fact that, as noted by Johnathan Guthrie, an election was approaching. ${ }^{104}$ Cameron's unexpected enthusiasm may thus have also been a political move intended to tap into the negative perception of foreign takeovers in the UK (discussed in section C).

Whilst Cameron's public warning against a potential takeover by ExxonMobil was in acknowledgement of the social considerations related to that takeover, it effectively pre-empted the formal review process of the PIT by announcing the government's position before the review had been completed. Such an ad hoc response, in addition to occurring outside and thus undermining the established legal process, raises questions as to whether the decision-making process could be considered objective or transparent, and as to the influence of political expediency.

ii) The Attempted Takeover of Unilever Plc by Kraft Heinz Co.

In February 2017, Kraft Heinz Co. (Kraft Heinz) made a surprise \$143 billion offer for the major Anglo-Dutch consumer goods company Unilever Plc (Unilever). ${ }^{105}$ When Kraft Heinz's bid was announced, two events occurred. First, trade unions began raising concerns about job displacement in relation to the takeover, ${ }^{106}$ and secondly, Theresa May was reported to have 'ordered officials to examine the proposed takeover to determine whether government intervention was necessary'. ${ }^{107}$

The proposed transaction would have been one of the largest takeovers in history, ${ }^{108}$ but only a few days after publicly announcing its bid, Kraft Heinz withdrew it. ${ }^{109}$ Factors which reportedly contributed to Kraft Heinz's decision to do this included: lack of public receptiveness to the transaction due to lingering reputational damage sustained by Kraft following its controversial takeover of Cadbury in 2010, Kraft Heinz's general reputation for relentlessly cutting costs after its previous acquisitions, and Unilever shareholder and board

\footnotetext{
${ }^{104}$ Jonathan Guthrie, 'BP shareholders need protecting from David Cameron' Financial Times (London, 27 April 2015) <https://www.ft.com/content/2c803100-ecc2-11e4-b82f-00144feab7de> accessed 4 September 2017. 105 Rob Davies, 'How Unilever foiled Kraft Heinz’s £115bn takeover bid’ The Guardian (London, 20 February 2017) <https://www.theguardian.com/business/2017/feb/20/how-unilever-foiled-kraft-heinzs-115m-takeoverbid-warren-buffett> accessed 4 September 2017.

106 Gwyn Topham 'Kraft Heinz withdraws Unilever takeover bid' (The Guardian, 19 February 2017) $<$ https://www.theguardian.com/business/2017/feb/19/kraft-heinz-unilever-shareholders-lobbies-uk-governmenttakeoverbid> accessed 4 September 2017.

107 Scheherazade Daneshkhu and others, 'Unilever calls for revamp of UK Takeover Code after Kraft bid' Financial Times (London, 14 March 2017) <https://www.ft.com/content/f85e6438-08b1-11e7-ac5a903b21361b43> accessed 4 September 2017.

108 Topham (n 106).

109 ibid; Martinne Geller and Pamela Barbaglia 'Kraft Heinz bids $\$ 143$ billion for Unilever in global brand grab' (Thomson Reuters, 17 February 2017) <http:/www.reuters.com/article/us-unilever-m-a-kraftidUSKBN15W18Y> accessed 4 September 2017.
} 
resistance to the offer, which was heavily loaded with debt. ${ }^{110}$ High levels of societal uncertainty following Brexit and a tense political attitude towards foreign takeovers at the time of the proposed takeover in general seemingly also amplified the aforementioned reputational factors in causing Kraft Heinz to withdraw its bid. ${ }^{111}$

Kraft Heinz's cancellation of its bid for Unilever in response to such pressure first emphasises that it is important to reduce social tensions concerning foreign takeovers in order to ensure that the review of such transactions has a chance to occur objectively, transparently and formally. Secondly, it highlights the genuine risk that foreign investors will be deterred by the uncertainty that the lack of such a process generates. ${ }^{112}$

iii) A Forum for the acknowledgement of Social Considerations and the Reinforcement of the Foreign Takeover Review Process

It is submitted that if a forum where social considerations can be heard and addressed in relation to foreign takeovers were to be introduced, there would be less social tension and controversy surrounding these transactions. Formal acknowledgement of these considerations in such a forum would enable society to better weather the uncertainty which arises from foreign takeovers. This would lessen the emergence of pressures which contribute to attempted takeovers, such as that by Kraft Heinz of Unilever, being abandoned before they are formally assessed. Politicians would, as a result, also be less inclined to pre-emptively block foreign takeovers from materialising, as there would be greater public trust in the formal regulation of these transactions.

The process by which foreign takeovers are reviewed would thereby be reinforced, and legal certainty for foreign investors and society surrounding these transactions would be enhanced.

\section{Reconceptualising the Task of Regulating Foreign Takeovers}

Regulating foreign takeovers should no longer be viewed as a choice between promoting economic growth or the protection of public interests. Instead, it should be viewed as a task of securing balance between these two objectives, whilst an effort is additionally made to manage social considerations within the process of regulating takeovers, thereby depoliticising the legal procedure and reducing social tensions. All three objectives are clarified below.

\footnotetext{
${ }^{110}$ Davies (n 105); Topham (n 106).

111 Theresa May's government identified a reform of foreign takeover regulations to give more weight to social considerations as one of its objectives several months prior to Kraft Heinz's proposed takeover of Unilever, but also outlined its intention to ensure that foreign investment in the UK is encouraged, see: The Conservative and Unionist Party (n 6).

${ }^{112}$ Alex Potter also discusses how takeovers are hindered where they are unfavourably perceived by the public, see: Potter (n 16).
} 
Promotion of economic growth is achieved where takeover regulations follow a principle of flexibility and are sufficiently liberal. This allows the free market to continue to provide the main impetus for foreign takeovers, thereby ensuring that capital is efficiently allocated and companies are well-managed, in line with investor interests. ${ }^{113}$

Public interests are protected where a country's fundamental interests, its general wellbeing and functioning, are preserved. This requires foreign takeovers, and specifically the practical effects they have on society, to be controlled. This is the objective of the UK's PIT, and is an objective which should be defined narrowly, due to the importance of avoiding protectionism and resisting the broadening of the PIT (as discussed previously in this paper).

The objective of managing social considerations within the process of regulating takeovers is achieved where social concerns arising from foreign takeovers can be discussed and assessed transparently and objectively - ie where they are a formal part of the merger control regime. This would allow people to feel that their concerns are heard, taken seriously, and acted upon where possible, and would therefore have the effect of reducing social tensions which arise in relation to foreign takeovers.

\section{E. EVALUATING THE CURRENT MERGER CONTROL REGIME}

\section{Critical Analysis of the PIT}

Public interest considerations can be construed broadly. This is likely due to the fact that, as discussed by Alex Chisholm and Nelsen Jung, the concept of public interest is in itself very difficult to define. This effect is highlighted by the open consideration in section 58(3), which provides that the Secretary of State can include new public interest considerations (where parliamentary approval is given), ${ }^{114}$ as well as by the lack of a clear working definition of national interest in section 58(2) - discussed in section B of this paper. ${ }^{115}$ It is submitted that the vague definition of the latter and the open-ended nature of the former convey to the public that the PIT provides politicians with an extremely broad discretion to block takeovers on public interest grounds.

This can have the effect of intensifying public 'pressure [on politicians] to intervene in specific cases where particular interests are threatened, ${ }^{116}$ and where politicians fail to do this, negative public perceptions and controversy regarding foreign takeovers in general are

\footnotetext{
${ }^{113}$ Davis and others (n 15).

114 EA 2002, s 58(3).

115 EA 2002, s 58(2).

116 ibid, 726; Chisholm and Jung (n 44) 7.
} 
elevated. Where they succeed in avoiding the application of the PIT by preventing a takeover from occurring at all, as ultimately happened in the cases discussed in section D, social considerations are hastily assessed outside of a formalised regulatory procedure, and the result is a review process which neither operates transparently, systematically nor efficiently, as well as one which discourages foreign investment.

\section{Critical Analysis of the Role of the Takeover Panel in Regulating Foreign Takeovers}

The Takeover Code and Panel are valued for being flexible, effective and fair. ${ }^{117}$ The Code provides the advantages of responsiveness, minimal tactical litigation, low costs (as the Panel does not charge parties to a bid when it issues guidance to them), and the ability to evolve proactively, in line with market developments. ${ }^{118} \mathrm{With}$ the rules on post-offer undertakings and intention statements discussed in sections $\mathrm{B}$ and $\mathrm{C}$, the Code has begun to enter into the sphere of managing societal tensions caused by foreign takeovers. ${ }^{119}$

The rule on post-offer undertakings was first applied in 2016, in relation to a takeover by Japanese technology company, Softbank Group Corp. (Softbank) of ARM Holdings Plc (ARM Holdings). Softbank undertook to 'at least double the employee headcount of ARM in the UK, increase the employee headcount of ARM outside the UK, and keep ARM's headquarters in Cambridge for five years'. ${ }^{120}$ It also agreed to procure post-offer undertakings relating to employee headcount and headquarters from ARM. ${ }^{121}$ In reflecting on this application of rule 19.5, it was observed that committing to an undertaking is a political act, as undertakings help secure favourable public and political perceptions of a transaction, and allow for the avoidance of complications brought about by political instability. ${ }^{122}$ The Takeover Panel monitors and enforces the process related to these undertakings. However, it should be noted that given the burdensome nature of the rules concerning post-offer undertakings, it is doubtful that Bidders will opt for them very often.

\footnotetext{
117 John Armour and David Skeel, 'Who Writes the Rules for Hostile Takeovers, and why? The Peculiar Divergence of US and UK Takeover Regulation' (2007) 95 The Georgetown Law Journal 1745, 1745-51.

118 ibid.

119 The Takeover Code, rr 19.5-6.

120 London Stock Exchange, 'ARM Holdings PLC Post-Offer Undertakings Statement' (30 November 2016) $<$ http://www.londonstockexchange.com/exchange/news/market-news/market-news-detail/other/13023642.html> accessed 4 September 2017.

121 ibid.

122 Gillian Fairfield and Antonia Kirkby, 'UK Takeover Code - Bidder Elects to Give Post-Offer Undertakings for the First Time' (Oxford Business Law Blog, 30 September 2016) <https://www.law.ox.ac.uk/business-lawblog/blog/2016/09/uk-takeover-code---bidder-elects-give-post-offer-undertakings-first $>$ accessed 4 September 2017; Andrew Thornton, 'First scheme of arrangement including post-offer undertakings sanctioned by the court' (Osborne Clarke, 12 October 2016) <http://www.osborneclarke.com/insights/first-scheme-of-arrangementincluding-post-offer-undertakings-sanctioned-by-the-court/> accessed 4 September 2017.
} 
It is feasible to contemplate extending the Panel's role in regulating and policing the takeover process to somehow provide for greater accommodation of social considerations, especially given that the Panel has already begun doing this via rules 19.5 and 19.6. However, it is submitted that this is unlikely to be a welcome reform.

Extending the Panel's role to encompass the regulation of public interest considerations would redefine the purpose of the Panel, as the Code emphasises that it is not intended to address competition or public interest matters. ${ }^{123}$ Redefining the purpose of the Panel, when it is currently respected for the efficiency with which it serves its existing narrower purpose, would not be desirable. The Panel would need to create a division for this new purpose, and to hire experts who have a specialised understanding of government investment policy and social concerns arising from foreign takeovers. This would involve changes to the Panel's current composition, as it is currently comprised of representatives from financial and business institutions, and of secondees from professional service industries that facilitate takeovers, consistent with the purpose which the Panel presently follows. ${ }^{124}$ Further, such a significant change in the Panel's purpose would also risk making the Panel's role more political, which would detract from the Panel's reputation for being informal, practical, impartial and objective.

\section{F. SUGGESTIONS FOR REFORM}

Broadly defined public interest considerations were identified as key criticisms of the current merger control regime in the above section. Additionally, it was emphasised that a reform extending the current role of the Takeover Panel is undesirable. This section suggests reforms which would improve the ability of the merger control regime to meet the three objectives identified as necessary in regulating foreign takeovers, namely, the promotion of economic growth, the protection of public interests, and the management of social considerations into the process of regulation.

In discussing the UK's current merger control regulations with two City law firm partners experienced in Mergers and Acquisitions and in dealing with the Takeover Panel, both recognised the need for the government to protect public interests in a context where uncertainty is rife. ${ }^{125}$ Both additionally acknowledged the difficulty of establishing a method

\footnotetext{
123 The Takeover Code, Introduction 2(a).

124 The Takeover Panel, 'Panel Membership' (The Takeover Panel, 2017) $<$ http://www.thetakeoverpanel.org.uk/structure/panel-membership > accessed 4 September 2017.

${ }^{125}$ Interview with Corporate M\&A Partner at major City law firm and former secondee at the Takeover Panel, London (London, United Kingdom, 26 June 2017); Interview with Corporate M\&A Partner at a Silver Circle City firm, London (London, United Kingdom, 31 July 2017).
} 
by which governments can achieve this, and of finding a way to simultaneously maintain the UK's favourable environment for foreign investment. In line with the evaluation of the current merger control regime conducted in section $\mathrm{E}$ of this paper, the partners were united in their opposition to broadening the PIT and reforming the role of the Takeover Panel. They speculated that a need may arise in the future to implement new, targeted rules to somehow address public concerns arising out of the more controversial and problematic takeovers, particularly given the significant societal disruption that $\mathrm{AI}$ is anticipated to bring in the coming years. ${ }^{126}$ These reflections have been considered in formulating the analysis which follows.

This section begins by examining the option of amending the PIT, and does not recommend that it should be broadened. Instead, it suggests first, that the vague definitions of the open consideration in section 58(3) and the consideration concerning national security in section 58(2) should be clarified and that secondly, a new independent body, called the Public Interest Commission (PIC) should be created. This body would have three tasks, namely, administering the PIT, providing a forum for social concerns arising out of proposed takeovers to be assessed and negotiated, and finally, providing policy recommendations to the government on how to mitigate the development of concerns in relation to foreign takeovers. The final part of this section evaluates these suggestions.

\section{Amending the PIT}

It is submitted that the public interest considerations contained in the PIT should be amended in order to ensure that the PIT is not perceived as allowing broad political discretion over foreign takeovers. The legislation should outline that there are three public interest considerations, but should more clearly specify the conditions that need to be fulfilled for each consideration to arise. The provisions outlining the considerations should reflect how each consideration has been applied in practice in the past. This would ensure that the UK's 'public interest', defined at the outset of this paper as its fundamental interests, general well-being and functioning, is afforded the same protection it has received to date.

Therefore, taking each of the three public interest considerations in the current PIT in turn, the consideration regarding media plurality and accurate presentation of the news should remain as it is, as it is already quite specific. ${ }^{127}$

The national interest consideration should outline specifically what national security covers: the maintenance of UK strategic capability, the protection of classified information in relation to military activities, and only the 'fundamental interests' of the state, such as the

126 ibid.

${ }^{127}$ EA 2002, ss 58(2A)-(2C). 
'maintenance of essential public services or the safe and effective functioning of the life of the state'. ${ }^{28}$

The open public interest consideration in section 58(3) should no longer allow the Secretary of State to introduce new considerations. ${ }^{129}$ Instead, it should explicitly specify only the consideration that has been used under this section to date: the protection of the security of UK financial markets. ${ }^{130}$

Politicians would as a result be exposed to less pressure from the public to enhance the protection of social considerations merely by virtue of vaguely worded legislation. By making it more straightforward and clear as to exactly what the PIT safeguards, the public will be less inclined to perceive the application of the PIT as a matter of political discretion.

\section{Creating a Public Interest Commission}

Aeron Davis and colleagues explored options of reforming the current foreign merger control regime in 2013. They recommended broadening the public interest test, ${ }^{131}$ which as noted above, this paper does not, but also outlined a suggestion for institutional reform, namely, 'setting up a new Public Interest Commission, independent of the Takeover Panel and the CMA'. ${ }^{132}$

The idea of creating the PIC has the potential to generate public confidence in the administration of the PIT, as the PIC could, in addition to administering the PIT, be formally responsible for actively managing any social considerations that arise out of foreign takeovers. Where the PIC's remit enables it to sufficiently address social concerns arising out of foreign takeovers, it would help to reduce demands for an expansion of the PIT, and would also reconcile the objectives of promoting economic growth, protecting public interests, and managing social considerations arising out of foreign takeovers. Active acknowledgement and the establishment of a process by which social considerations can be managed would be a proactive, responsive way of mitigating societal uncertainty which is only expected to increase in the future. Suggestions for the structure and functioning of the proposed PIC are outlined in the remainder of this section.

a) The Composition of a Public Interest Commission

It is submitted that the proposed PIC should have three divisions: an Executive Panel, a Social Consideration Panel and a Review Committee.

${ }^{128}$ This was how the UK argued public security should be defined in Campus Oil (n 36), para 23; EA 2002 S58(2).

129 EA 2002, s 58(3).

${ }^{130}$ Liddell and Allen (n 30) 725.

${ }^{131}$ Davis and others (n 15) 13.

132 ibid 17. 
i) Executive Panel

The Executive Panel should be the division that administers the PIT (as amended in accordance with the suggestions outlined above). This is the body that has the final decision on whether a merger should be approved, conditioned, or blocked on public interest grounds, and in deciding this, the Panel should act objectively. The Executive Panel should also be in charge of negotiating and securing UILs (as they are currently negotiated and secured by the Secretary of State) where necessary. The Panel's decision-making should be subject to judicial review and should additionally be subject to rules formulated with a view to ensuring that the Panel acts objectively in order to provide adequate and proportionate protection of the public interests reflected in the amended PIT.

The amended PIT and its administration by the PIC should be enforceable in a manner similar to the enforceability of the Takeover Code. ${ }^{133}$ The Executive Panel of the PIC should be responsible for applying for court enforcement where this might be necessary in relation to a negotiated and secured UIL. Court enforcement should also be dealt with by the Executive Panel in relation to post-offer undertakings committed to by a party to a transaction, which would be discussed and negotiated by the Social Consideration Panel, as outlined below.

ii) Social Consideration Panel

The role of the Social Consideration Panel should be that of conducting research, and of acting as a mediator between the parties who are affected by a proposed takeover and the parties to that takeover. Effectively, the Social Consideration Panel's purpose should be to provide a forum for concerns related to foreign takeovers to be heard, assessed and acted upon in a more formalised, structured and discursive manner than that which is currently provided for under the rules in the Takeover Code on post offer undertakings and statements of intention (see sections $\mathrm{B}$ and $\mathrm{C}$ ).

The conditions for the application of the current PIT would not change with the amendments to the PIT suggested above. When a proposed takeover is reviewable under the PIT, the Social Consideration Panel should conduct a mandatory evaluation of the social considerations at stake. If any social considerations arise, there should be a mandatory discussion between the Social Consideration Panel and the specifically interested stakeholders: the Bidder, the Target, and appropriate representatives for those whose interests (in terms of social considerations) are affected by the proposed transaction.

${ }^{133}$ Companies Act 2006, s 955. 
The Panel's objective should be to act as the intermediary between these parties, and it should take an active role in leading a discussion about the social considerations in question (which may include the concerns that have arisen in relation to foreign takeovers thus far regarding job displacement, the protection of key national industries or companies, and tax avoidance by foreign companies). Furthermore, the panel should lead the negotiation on how best to address the social considerations. This negotiation may lead parties to enter into postoffer undertakings. If so, it should be the Social Consideration Panel's role to monitor these, as well as any statements of intention (however, the Executive Panel should remain in charge of enforcement).

To clarify, the Social Consideration Panel's role should be to identify, assess, and at a minimum, require that a discussion about social considerations takes place in the case of PITreviewable proposed mergers. Whilst the parties would not be bound to address social considerations via statements of undertaking and intention, the existence of a Social Consideration Panel would at least ensure that parties to foreign takeovers begin the pursuit of a transaction mindful of social considerations and of the potential reputational risk associated with failing to engage with them in good faith. Softbank's willingness to commit to undertakings during its acquisition of ARM Holdings discussed in section E.2 indicates that this role of the Social Consideration Panel might be feasible and constructive.

Additionally, taking SoftBank's willingness to commit to the undertakings discussed in section E. 2 as a model for how companies may wish to take an active role in reducing societal uncertainty caused by foreign takeovers in the future, the Bidder or Target of a proposed takeover which is not PIT-reviewable, should also have the option to voluntarily submit itself to the jurisdiction of the Social Consideration Panel. Providing this option for parties to opt into the remit of the Social Consideration Panel would ensure that they are able to benefit from a review process which is open and non-arbitrary, whilst demonstrating that they too are concerned about the effects of the proposed transaction on society. Where this option is exercised, it could significantly reduce public and political instability, and help the public feel more comfortable in managing the effects of foreign takeovers.

Furthermore, in light of the societal uncertainty currently emerging from Brexit and expected to grow in the coming years due to the increasing integration of AI into society, it would be reasonable to also consider introducing a requirement for Bidder companies proposing takeovers which would produce enterprises above a certain size (measured by reference to factors such as revenue, market share or number of employees) to issue a public statement detailing why they are not opting into a review by the Social Consideration Panel. 
This would extend a degree of protection of public interests and social considerations to nonPIT reviewable transactions.

A summary of the proposed scope of the PIT and the Social Consideration Panel's evaluation of potential transactions is provided in Figure 1 below.

Figure 1-Scope of Application of the PIT and Social Consideration Panel's Evaluation

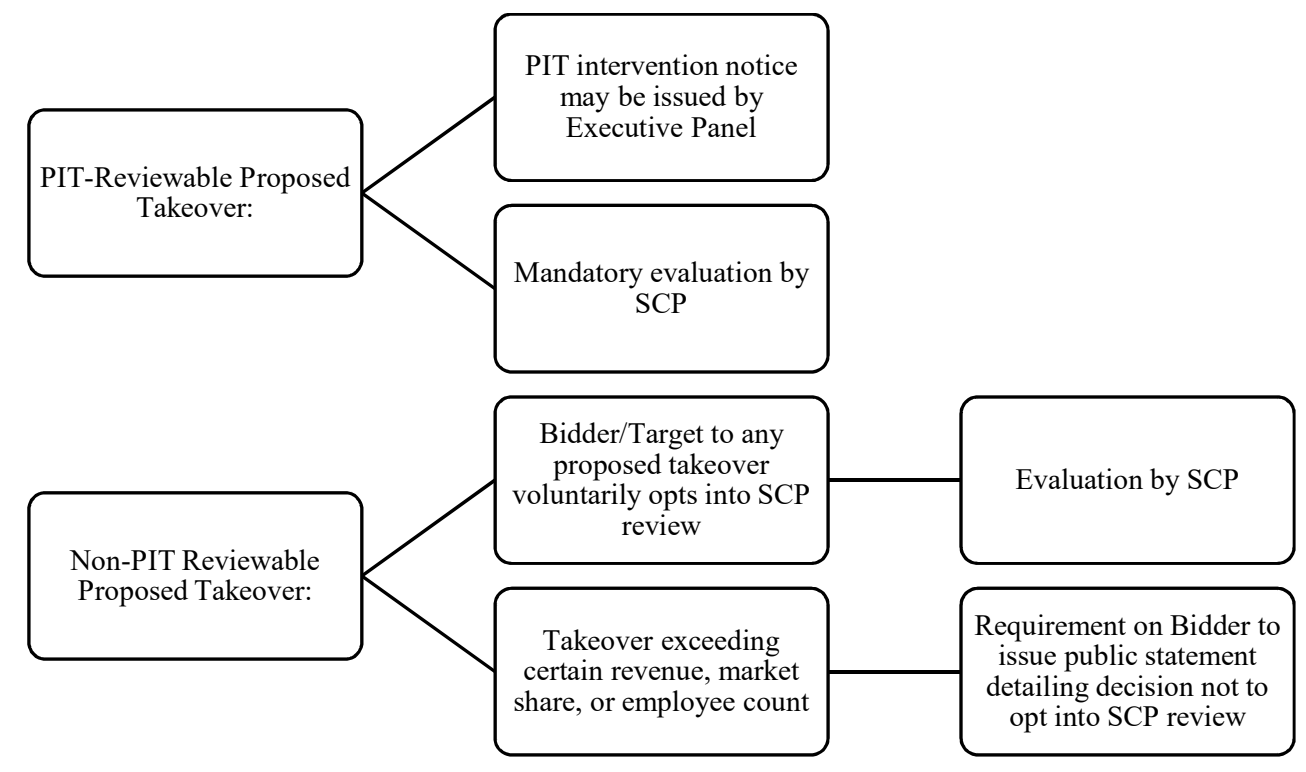

The Social Consideration Panel should seek to complete its tasks transparently, and should publish updates on discussions, negotiations, voluntary opt-ins and the monitoring of post-offer undertakings and intention statements, hopefully increasing the incentives on all parties to engage in good faith. The members of the Social Consideration Panel could include academics or professionals with extensive knowledge or expertise in areas including sociology, psychology, economics, finance, public policy, and management. They should be able to identify, investigate, assess and address social concerns, perhaps with the help of representatives from trade unions, the Secretary of State, and leading figures in industries that are concerned about the effects of a proposed takeover.

iii) Review Committee

The final task of the Social Consideration Panel should be to produce a report for the Review Committee where a need is identified to issue policy recommendations or solutions as to how the government can aid in the mitigation of social tensions caused by foreign takeovers. This may arise, for example, in relation to a completed takeover which, despite having proceeded through the negotiation process led by the Social Consideration Panel, still has such 
a significant impact after its completion that there is a need for the government to introduce new policies or implement new projects in order to help society manage similar effects of a given foreign takeover, or the effects of foreign takeovers in the future.

The Review Committee should, like the Takeover Panel's Code Committee, ${ }^{134}$ coordinate a call for submissions from academics, the Secretary of State, and other high-level representatives of interested parties. Following this, the Review Committee should conclude what policies/projects should be implemented, or whether the PIT should be reformed for future transactions. The report should specify how, and should be submitted to the government for consideration. In addition to this, the Review Committee should be consulted in the reverse scenario - ie if any initiatives are taken by the government to reform the PIT.

\section{Evaluation}

The introduction of a Social Consideration Panel would help the merger control regime in the UK to be flexible and responsive to public perceptions of foreign takeovers, as the social considerations which arise in relation to them would be dealt with formally and openly by the Social Consideration Panel. Additionally, this Panel would enable the interests of the public, the state and foreign investors to be collectively responded to: the public's concerns about foreign takeovers would be mitigated, the state's desire to promote economic growth would be fulfilled whilst maintaining the protection the current PIT has provided, and foreign investors would enjoy a clear, non-arbitrary review process in relation to any takeovers that they proposed. This process would also allow foreign investors greater options to manage public and political perceptions of a takeover.

i) Economic growth and investor interests

It is submitted that the suggestions are conducive to the objective of economic growth because the amendments to the PIT do not change the PIT's scope in practice. They merely clarify and increase legal certainty surrounding the regulation of foreign takeovers by reducing vague statutory wording. Additionally, the introduction of a PIC would create a clear procedure for administering the PIT and presents an open, formal forum within which social considerations can be assessed constructively, and actions to be taken can be formally negotiated. However, a mandatory process of discussing and potentially negotiating social considerations where a proposed takeover is reviewable under the PIT would add to the regulations that takeovers are subject to. This is a disadvantage of the above suggestion, but it is submitted that this would not be problematic, because first, the regulation of takeovers in the

134 The Takeover Panel, 'Code Committee' (The Takeover Panel, 2017) $<$ http://www.thetakeoverpanel.org.uk/structure/committees/code-committee> accessed 4 September 2017. 
UK is currently quite efficient, streamlined and cost-efficient. There is therefore room to add the additional regulatory mechanism of the PIC, especially given the benefits it would bring. Secondly, it seems feasible that adding the PIC would be embraced by foreign investors, especially given the example of SoftBank's willingness to commit to undertakings concerning societal effects of its takeover of ARM Holdings. SoftBank's willingness indicates that companies themselves are beginning to recognise the value of being considerate of social considerations.

Furthermore, the introduction of the PIC should have the effect of reducing demands for the expansion of the PIT, as the PIC will address social considerations and concerns arising out of foreign takeovers, as will now be discussed.

ii) Social considerations

It is submitted that the suggestions for reform are conducive to the final objective identified as key to regulating foreign takeovers in section D.3: managing social considerations. The proposed Social Consideration Panel would manage these considerations by assessing any social concerns that arise in relation to a foreign takeover, and leading a negotiation between interested parties to ascertain how best to address them. This would reduce social tensions in society concerning foreign takeovers, as affected people would be directly or indirectly involved, and would feel that their concerns were being taken seriously and acted upon where possible, pursuant to negotiations.

Furthermore, the updates published by the Social Consideration Panel about discussions, negotiations and the status of any post-offer undertakings or intention statements would also help create an incentive for parties to a transaction to be conscious of social considerations so as to avoid reputational damage. This would mean that the pressure for increased protection of social considerations would be increasingly directed at companies, and less at politicians.

\section{G. CONCLUSION}

It was recommended in this paper that the regulation of foreign takeovers be approached as a task of balancing three objectives: the promotion of economic growth, the protection of public interest, and the management of social considerations. In line with this, it was suggested that a forum for social considerations arising in the context of foreign takeovers to be heard and assessed be introduced. It was emphasised that the reforms proposed would have the potential to reduce social tensions in relation to foreign takeovers, thereby making them less controversial. This is an attractive outcome, as it would have the effect of easing pressure on 
politicians and reducing the lack of public trust in foreign takeovers. It is important that this be achieved, given the heightened controversy and societal disruption that takeovers are bound to cause in societally uncertain times, such as those following Brexit, and those to come as AI is increasingly integrated into society. In this context, the law should be actively seeking to mitigate the heightened social tensions caused by foreign takeovers, whilst also ensuring that the method by which they are regulated is objective, transparent and conducive to legal certainty. 